\title{
Комплексна фізична реабілітація людей похилого віку у ранні терміни після інсульту
}

\author{
УДК: 616.831-005.1-084-053.9
}

\author{
В. В. Клапчук, А. О. Мирненко, Д. А. Пономарьов
}

Запорізький національний технічний університет, Запоріжжя, Україна

\begin{abstract}
Резюме. Мета. Підвищення ефективності фізичної реабілітації людей похилого віку на стаціонарному етапі реабілітації після перенесеного інсульту. Методи. Оцінка рухливості суглобів, моменту сили згиначів і розгиначів гомілки та стегна, рухових функцій та координації рухів, м'язового тонусу верхньої кінцівки, життєвої ємності легень, стійкості до гіпоксії, проб Розенталя та Лебедєва, індексу Робінсона та адаптаційного потенціалу серцево-судинної системи, активності хворих у повсякденному житті, його якості, показників реактивної та особистісної тривожності. Результати. Обстежено 29 чоловіків віком 58-64 роки у ранні терміни після інсульту, які перебували на розширеному ліжковому та напівліжковому (палатному) рухових режимах. 3 числа засобів фізичної реабілітації було призначено лікувальну гімнастику, масаж та електростимуляцію м'язів з біологічним зворотним зв'язком на апараті ТРЕНАР-02. Висновки. Комплексна фізична реабілітація в умовах стаціонару дозволяє досягти позитивних статистично достовірних змін рухливості суглобів, моменту сили згиначів і розгиначів гомілки та стегна, рухових функцій та координації рухів, м'язового тонусу верхньої кінцівки. Про ефективність використаного методичного підходу свідчать позитивні зміни зовнішнього дихання та стійкості до гіпоксії, індексу Робінсона та адаптаційного потенціалу серцево-судинної системи, підвищення активності хворих у повсякденному житті, його якості, а також покращення показників реактивної та особистісної тривожності. Отримані результати дозволяють рекомендувати запропонований реабілітаційний комплекс для впровадження в практику фізичної та реабілітаційної медицини.

Ключові слова: фізична реабілітація, похилий вік, інсульт.
\end{abstract}

\section{Комплексная физическая реабилитация людей пожилого возраста в ранние сроки после инсульта}

\author{
В. В. Клапчук, А. А. Мирненко, Д. А. Пономарёв \\ Запорожский национальный технический университет, Запорожье, Украина
}

Резюме. Цель. Повышение эффективности физической реабилитации людей пожилого возраста на стационарном этапе реабилитации после перенесенного инсульта. Методы. Оценка подвижности суставов, момента силы згибателей и разгибателей голени и бедра, двигательных функций и координации движений, мышечного тонуса верхней конечности, жизненной емкости легких, устойчивости к гипоксии, проб Розенталя и Лебедева, индекса Робинсона и адаптационного потенциала сердечно-сосудистой системы, активности больных в повседневной жизни, ее качества, показателей реактивной и личностной тревожности. Результаты. Обследовано 29 мужчин в возрасте 58-64 года в ранние сроки после инсульта, которые находились на расширенном постельном и полупостельном (палатном) двигательных режимах. Из средств физической реабилитации назначались лечебная гимнастика, массаж и электростимуляция мышц с биологической обратной связью на аппарате ТРЕНАР-02. Выводы. Комплексная физическая реабилитация в условиях стационара позволяет достичь позитивных статистически достоверных изменений подвижности суставов, момента силы сгибателей и разгибателей голени и бедра, двигательных функций и координации движений, мышечного тонуса верхней конечности. Об эффективности использованного методического подхода свидетельствуют позитивные изменения внешнего дыхания и устойчивости к гипоксии, индекса Робинсона и адаптационного потенциала сердечно-сосудистой системы, повышение активности больных 
в повседневной жизни, ее качества, а также улучшения показателей реактивной и личностной тревожности. Полученные результаты позволяют рекомендовать предложенный реабилитационный комплекс для внедрения в практику физической и реабилитационной медицины.

Ключевые слова: физическая реабилитация, пожилой возраст, инсульт.

\title{
Complex physical rehabilitation of the elderly at the early stages after a stroke V. V. Klapchuk, A. O. Mirnenko, D. A. Ponomaryov
}

Zaporizhzhia National Technical University, Zaporizhzhia, Ukraine

\begin{abstract}
Objective. Improving the efficiency of physical rehabilitation of the elderly at the inpatient rehabilitation stage after a stroke. Methods. Assessment of joint mobility, hip flexor and extensor torque, motor functions and coordination of movements, upper extremity muscle tone, vital capacity, hypoxia resistance, Rosenthal and Lebedev tests, Robinson's index and cardiovascular system adaptation potential, patients' everyday activity, life quality, indices of reactive and personal anxiety. Results. 29 males aged 58-64 years on extended bed and semi-bed (ward) motor regimens were examined at the early stages after stroke. Among physical rehabilitation means therapeutic gymnastics, massage and electrical stimulation of muscles with biological feedback on the TRAINAR-02 device were put on. Conclusions. Complex physical rehabilitation in a hospital allows to achieve positive statistically significant changes in joint mobility, hip and ankle flexor and extensor torques, motor functions and coordination of movements, muscular tone of the upper extremity. The effectiveness of the methodological approach is confirmed by positive changes in external respiration and resistance to hypoxia, the Robinson index and the cardiovascular system adaptation potential, increased activity of patients in daily life, its quality, as well as improved indices of reactive and personal anxiety. The obtained results allow to recommend the proposed rehabilitation complex for introduction into the practice of physical and rehabilitation medicine.
\end{abstract}

Keywords: physical rehabilitation, elderly age, stroke.

Постановка проблеми. Аналіз останніх досліджень і публікацій. У більшості держав світу інсульт $\epsilon$ другою за значущістю причиною збільшення смертності після серцево-судинних захворювань. В Україні щороку діагностують близько 125 тис. випадків інсульту. Третина пацієнтів з перенесеним інсультом - люди працездатного віку, однак тільки 10-20\% з них повертаються до активного способу життя. Інсульт - це патологія, що вражає працездатне населення, призводячи до тривалої госпіталізації, стійкої інвалідизації хворих, погіршення якості життя їхніх сімей i значних економічних витрат держави $[6,7]$.

Відновлення порушених функцій у пацієнтів, які перенесли інсульт, обґрунтовано вважається одним із пріоритетних напрямків медичної реабілітації. Причинами, що зумовлюють це, $\epsilon$ не тільки різноманіття і вираженість функціональних розладів, що розвиваються після перенесеного гострого порушення мозкового кровообігу, але і постійне зростання кількості пацієнтів 3 даною патологією $[4,16]$.

Дихальні порушення - найбільш часті і важкі ускладнення мозкових інсультів. Вони виникають більше ніж у половини хворих і в $14 \%$ випадків $\epsilon$ основною причиною смерті. 3 цієї причини проблеми дихальних порушень у хворих з мозковими інсультами виходять за межі неврології та створюють серйозну міждисциплінарну проблему сучасної медицини [17].

У процесі фрізичної реабілітації застосовують такі методи: лікування положенням; масаж; пасивні вправи; дихальні вправи (активні прийоми); гіпоксичне тренування; логопедичну і фонопедичну корекцію; подальшу поступову активну вертикалізацію хворих; онтогенетично обумовлену кінезитерапію, спрямовану на подальше стимулювання рефлекторних реакцій відповідно до ієрархічних принципів побудови фрункцій у ЦНС; механотерапію, у тому числі роботизовану; заняття на циклічних тренажерах; динамічну пропріокорекцію, навчання побутових навичок (ерготерапію); рефлексотерапію; психотерапію $[5,13]$. Однак питання комплексної фрізичної реабілітації хворих після інсульту, яка у похилому віці повинна мати свої особливості, вивчено недостатньо.

Із 2015 р. Україна приєдналася до європейських проектів, спрямованих на покращення допомоги пацієнтам 3 інсультом. Попри тяжку економічну ситуацію, складний та болючий процес реформування галузі охорони здоров'я, триває активна співпраця із проектом ESO-EAST («Enhancing and Accelerating Stroke Treatment»«Оптимізація та прискорення лікування інсульту») та ініціативою «Angels». В Україні створено 
спільний фаховий комітет експертів цього міжнародного проекту, працює спеціально сформована робоча група з цього напрямку.

Мета дослідження - підвищення ефрективності фрізичної реабілітації людей похилого віку на стаціонарному етапі реабілітації після перенесеного інсульту.

Методи й організація дослідження. $\mathrm{Ha}$ базі КУ «Міська клінічна лікарня № 6» М. Запоріжжя за участю А. О. Мирненко було обстежено 29 чоловіків віком 58-64 роки у ранні терміни після перенесеного інсульту, яким було призначено різні види ліжкового режиму (розширений ліжковий та напівліжковий, тобто палатний). Термін їх лікування становив 55 днів. Критеріями включення в дослідження були: фрункціональна готовність до вертикалізації; ясна свідомість; відсутність важкої соматичної патології, ішемічних змін на ЕКГ, серцевої недостатності, дефректів опорно-рухового апарату, що ускладнюють заняття фрізичними вправами; відсутність грубої сенсорної афазії і когнітивних (пізнавальних) розладів, що перешкоджають активному залученню хворих у реабілітаційні заходи.

Усі обстежені були розподілені на дві групи: контрольну (14 хворих) та основну (15 хворих). Курс реабілітації пацієнтів контрольної групи складався зі стандартної програми лікувальної гімнастики і масажу [5]. Процедури лікувальної гімнастики включали 8-10 гімнастичних вправ у положенні лежачи, які виконували п'ять разів на тиждень із реабілітологом, а в інші дні - самостійно за завданням протягом 40-50 хв. Одночасно практикували вправи у ходьбі на місці. При цьому основну увагу хворого зосереджували на відтворенні правильного рисунка ходьби. Поряд з цим проводили лікувальний масаж по 10-15 хв курсом 10-15 процедур. Основна група додатково до ЛФК і масажу проходила курс електростимуляції з біологічним зворотним зв'язком на апараті ТРЕНАР-02. Його програма «Донор» передбачала тренування вимушених рухів під впливом електростимуляції м'язів за програмами, які «зчитуються» 3 власних здорових м'язів пацієнта або м'язів іншої людини (інструктора) під час їхніх довільних скорочень і передаються м'язам, які тренуються, у режимі «он-лайн». Як наслідок, аферентна пропріоцепція від рухів пошкодженої кінцівки стає ефективнішою.

У процесі досліджень визначали рухливість у кульшових, надп'ятково-гомілкових, плечових, ліктьових суглобах, суглобах кисті і стопи за допомогою кутоміра з двома браншами в градусах за п'ятибальною шкалою [2].
Для вимірювання моменту сили м'язів стегна і гомілки пацієнта просили виконати певні рухи в умовах опору, або навпаки - пацієнт чинив опір активним діям. Для клінічного оцінювання моменту сили м'язів використовували п'ятибальну шкалу, запропоновану О. В. Марксом [2].

Шкала оцінки рухової активності хворих дозволяла оцінювати статичну рівновагу i ходьбу хворих під час виконання ними конкретних рухових завдань. Ступінь рухових порушень оцінювали за шкалою Тінетті. Визначали також стійкість у поштовхових пробах, виконання оберту. Загальний бал наприкінці дозволяв виявити відсутність або наявність легких, середніх і значних порушень рухової активності [9].

Імпрегнаційний метод використовували для визначення просторових параметрів ходьби: ширини і бази кроку. Визначення швидкості ходьби виконували шляхом підрахунку кількості поодиноких кроків за 60 с при звичному для хворого темпі руху [14].

М'язовий тонус оцінювали за модифрікованою шкалою спастичності Ашфорт [10].

Вивчення фуннціонального статусу пацієнта проводилося за допомогою індексу повсякденної активності Бартел, який відображає здатність пацієнта приймати ванну, вмиватися, одягатися, контролювати тазові функції, користуватися туалетом, переходити $з$ ліжка на стілець, пересуватися, а також підніматися по сходах [11].

Для оцінювання фрункціонального стану дихальної системи сухим портативним спірометром (фрірма КПО «Медапаратура») визначали життєву ємність легенів (ЖЕЛ) у стані спокою і застосували фрункціональні проби (Розенталя, Лебедєва) та гіпоксичні (Штанге і Генча). Отриману під час спірометрії величину ЖЕЛ називали фрактичною (ФЖЕЛ) і порівнювали з належними величинами (НЖЕЛ) [15].

Для оцінювання функціонального стану серцево-судинної системи вимірювали частоту пульсу на променевій артерії та артеріальний тиск у стані спокою в положенні сидячи за допомогою цифрового тонометра Medical UA-777 фірми «AND A \& D». Розраховували індекс Робінсона, а також індекс адаптаційного потенціалу серцево-судинної системи [1, 8].

Для оцінювання особистісної і реактивної тривожності пацієнтів використовували шкали Спілбергера-Ханіна, розроблені Спілбергером у 1966-1973 pp. [8].

Якість життя хворих оцінювали за модифікованою версією неспецифрічного опитувальника SF-36. Опитувальник адаптований і валідизо- 
ваний Міжнаціональним центром дослідження якості життя [3].

Під час статистичної обробки матеріалу розраховували середнє (М), його стандартну помилку (m). Визначали мінімальну кількість вибірки, необхідну для достовірних висновків. Достовірність різниці (р) оцінювали за t-критерієм Стьюдента. При p < 0,05 її вважали статистично достовірною [12].

Результати дослідження та їх обговорення. Під час первинного обстеження за всіма використаними методиками різниця показників у контрольній і основній групах була статистично недостовірною, тобто вони були придатними для порівняння $(p>0,05)$. Оцінювання есрективності реабілітаційного курсу шляхом порівняння контрольної та основної груп дало такі результати.

Рухливість суглобів під час первинного обстеження у контрольній групі становила 1,87 $\pm 0,14$ бала, в основній $-1,75 \pm 0,21$ бала, а під час заключного обстеження - відповідно 2,31 \pm 0,13 та 3,25 \pm 0,19 бала. Якщо під час первинного обстеження показники в групах не мали статистично значущої різниці, то під час заключного кількість балів в основній групі була достовірно більшою, ніж у контрольній $(p<0,05)$.

Динаміка значень моменту сили м'язів згиначів і розгиначів гомілки та стегна була такою: гомілки - на початку дослідження у контрольній групі $1,15 \pm 0,24$ бала, в основній $-1,16 \pm 0,23$, наприкінці дослідження - відповідно 1,69 $\pm 0,23$ і $2,45 \pm 0,16$ бала $(p<0,05)$; стегна - на початку дослідження у контрольній групі 1,42 $\pm 0,29$, в основній $-1,44 \pm 0,30$ бала, наприкінці дослідження - відповідно 2,19 \pm 0,27 і 3,15 \pm 0,25 бала ( $<<0,05)$.

Зміни показників рухової фрункції та координації під впливом реабілітаційного комплексу наведено у таблиці 1.

3 таблиці 1 видно, що на відміну від контрольної в основній групі відбулося достовірне зростання досліджуваних показників рухових фрункцій та координації ( $<<0,05)$, а в контрольній групі статистично достовірних змін не виявлено $(p>0,05)$. Так, загальний бал за шкалою Тінетті у хворих основної групи збільшився на 38,5% (при 10,5 \% контрольної групи), бал за субшкалою стійкості зріс на 32,3 \% (при 15,2 \% контрольної групи), бал за субшкалою ходьби зріс на 42 \% (при 16,9 \% контрольної групи), база кроку зменшилася на 30,7 \% (при 13,6\% контрольної групи), відношення довжини кроку пацієнта до зросту хворого збільшилася на 44,8 \% (при 10,7 \% контрольної групи), частота кроку зросла на 24,8 \% (при 7,8 \% контрольної групи).
ТАБЛИЦЯ 1 - Динаміка рухових функцій та координації рухів $(\mathbf{M} \pm \mathrm{m})$

\begin{tabular}{|c|c|c|c|}
\hline \multirow{2}{*}{ Група } & \multicolumn{2}{|c|}{ Дослідження } & \multirow{2}{*}{$\begin{array}{l}\text { Достовірність } \\
\text { різниці }\end{array}$} \\
\hline & початкове & заключне & \\
\hline \multicolumn{4}{|c|}{ Шкала Тінетті, загальний бал } \\
\hline $\begin{array}{l}\text { Контрольна } \\
\text { Основна }\end{array}$ & $\begin{array}{l}25,75 \pm 3,54 \\
24,87 \pm 4,14\end{array}$ & $\begin{array}{l}28,46 \pm 3,21 \\
34,45 \pm 2,15\end{array}$ & $\begin{array}{l}p>0,05 \\
p<0,05\end{array}$ \\
\hline \multicolumn{4}{|c|}{ Шкала Тінетті, субшкала стійкості, бали } \\
\hline $\begin{array}{l}\text { Контрольна } \\
\text { Основна }\end{array}$ & $\begin{array}{l}15,23 \pm 1,65 \\
15,98 \pm 1,88\end{array}$ & $\begin{array}{l}17,54 \pm 1,61 \\
20,14 \pm 1,56\end{array}$ & $\begin{array}{l}p>0,05 \\
p>0,05\end{array}$ \\
\hline \multicolumn{4}{|c|}{ Шкала Тінетті, субшкала ходьби, бали } \\
\hline $\begin{array}{l}\text { Контрольна } \\
\text { Основна }\end{array}$ & $\begin{array}{l}8,65 \pm 1,32 \\
9,12 \pm 1,42\end{array}$ & $\begin{array}{l}10,11 \pm 1,29 \\
12,95 \pm 1,21\end{array}$ & $\begin{array}{l}p>0,05 \\
p<0,05\end{array}$ \\
\hline \multicolumn{4}{|c|}{ База кроку, см } \\
\hline $\begin{array}{l}\text { Контрольна } \\
\text { Основна }\end{array}$ & $\begin{array}{l}12,46 \pm 1,76 \\
12,32 \pm 1,36\end{array}$ & $\begin{array}{c}10,76 \pm 1,62 \\
8,54 \pm 1,28\end{array}$ & $\begin{array}{l}p>0,05 \\
p<0,05\end{array}$ \\
\hline \multicolumn{4}{|c|}{ Довжина кроку · зріст ${ }^{-1}$, см } \\
\hline $\begin{array}{l}\text { Контрольна } \\
\text { Основна }\end{array}$ & $\begin{array}{l}0,28 \pm 0,03 \\
0,29 \pm 0,05\end{array}$ & $\begin{array}{l}0,31 \pm 0,04 \\
0,42 \pm 0,02\end{array}$ & $\begin{array}{l}p>0,05 \\
p<0,05\end{array}$ \\
\hline \multicolumn{4}{|c|}{ Частота кроку, крок $\cdot \mathrm{c}^{-1}$} \\
\hline $\begin{array}{l}\text { Контрольна } \\
\text { Основна }\end{array}$ & $\begin{array}{l}1,28 \pm 0,11 \\
1,29 \pm 0,08\end{array}$ & $\begin{array}{l}1,38 \pm 0,09 \\
1,50 \pm 0,07\end{array}$ & $\begin{array}{l}p>0,05 \\
p>0,05\end{array}$ \\
\hline
\end{tabular}

Порівняння між групами на етапі заключного обстеження за більшістю показників таблиці 1 було статистично достовірним ( $<<0,05)$, а за субшкалою стійкості та частотою кроку при р $>0,05$ основної групи виявлено позитивну тенденцію в межах груп.

У контрольній групі м'язовий тонус верхньої кінцівки під час первинного обстеження становив 2,76 $\pm 0,33$ бала, в основній $-2,79 \pm 0,31$, під час заключного обстеження - відповідно $2,21 \pm 0,24$ та $1,12 \pm 0,18$ бала $(p<0,05)$. Нa нижній кінцівці під час первинного обстеження у контрольній групі він досягав 2,54 \pm 0,34 бала, в основній $-2,51 \pm 0,38$ бала, а під час заключного обстеження - відповідно 2,09 $\pm 0,31$ та $0,98 \pm 0,29$ бала ( $<<0,05)$.

Значення індексу Бартел, який оцінює активність у повсякденному житті, були такими: під час початкових досліджень у контрольній групі $52,31 \pm 5,78$ бала, в основній $-54,13 \pm 6,21$; під час заключних у контрольній групі $-59,45 \pm 4,54$, в основній $-69,22 \pm 4,21$ бала $(p<0,05)$.

На початку дослідження у хворих обох груп спостерігалися знижені показники зовнішнього дихання. Зокрема, відсоток ФЖЄЛ від НЖЄЛ становив у контрольній групі 59,13 $\pm 2,53 \%$, а в основній $-58,43 \pm 2,32 \%$. В основній групі після реабілітаційного курсу він зріс на $17,7 \%$, а в контрольній - тільки на 5,6 \% і досягав відповідно $68,77 \pm 2,12 \%$ та $62,44 \pm 2,21 \%$, що має статистично значущу різницю $(p<0,05)$.

Вихідна оцінка стійкості до гіпоксії за пробами із затримкою дихання Штанге та Генча дала 
такі результати: під час початкового дослідження у контрольній групі затримка дихання на вдиху $29,55 \pm 1,33$ с, на видиху $-18,12 \pm 1,28$ с , в основній відповідно $29,96 \pm 1,45$ і 18,54 $\pm 1,25$ с; у заключному дослідженні затримка дихання на вдиху становила в контрольній групі $32,76 \pm 1,31$ с, на видиху $-20,21 \pm 1,26$ с, в основній - відповідно $36,82 \pm 1,14$ i $22,56 \pm 1,19$ c $(p<0,05)$.

Значення проб Розенталя і Лебедєва у хворих обох груп протягом дослідження не мали статистично достовірної різниці ( $>>0,05)$.

Зміни значень індексу Робінсона (подвійного добутку) і адаптаційного потенціалу під впливом реабілітаційного курсу наведено у таблиці 2.

3 таблиці 2 видно, що в основній групі індекс Робінсона знизився достовірно на 22,1\%, що свідчить про зростання обмінно-енергетичних процесів у міокарді до середнього рівня. У контрольній групі індекс змінився недостовірно лише на 5,2 \% і відповідав відмітці «нижче від середнього». Напруження адаптаційного потенціалу знизилося в основній групі на $34,5 \%$, внаслідок чого оцінка «зрив адаптації», визначена на початку дослідження, була покращена на два пункти до значення «напруження механізмів адаптації». У контрольній групі індекс змінився недостовірно тільки на 8,8 \%, що відповідало «незадовільній адаптації».

У процесі дослідження динаміки показників реактивної та особистісної тривожності за тестом Спілбергера-Ханіна виявлено суттєве покращення результатів в обох групах хворих. Так, реактивна тривожність вірогідно знизилася в основній групі на 49,2 \%, а в контрольній - на 20,6\% (р < 0,05); особистісна тривожність вірогідно знизилася в основній групі на 41,7 \% ( $<0,05)$, а в контрольній групі її зміни на 15,1 \% були недостовірними ( $>>0,05)$.

ТАБЛИЦЯ 2 - Динаміка значень індексу Робінсона й адаптаційного потенціалу серцево-судинної системи $(M \pm m)$

\begin{tabular}{|l|c|c|c|}
\hline \multirow{2}{*}{ Групи } & \multicolumn{2}{|c|}{ Дослідження } & Достовірність \\
& різниці \\
\cline { 2 - 3 } & початкове & заключне & \\
\hline \multicolumn{4}{|c|}{ Індекс Робінсона, ум. од. } \\
Контрольна & $110,51 \pm 2,15$ & $104,76 \pm 2,12$ & $\mathrm{p}>0,05$ \\
Основна & $109,86 \pm 2,23$ & $85,54 \pm 2,13$ & $\mathrm{p}<0,05$ \\
& Адаптаційний потенціал, бали \\
Контрольна & $3,98 \pm 0,17$ & $3,63 \pm 0,14$ & $\mathrm{p}>0,05$ \\
Основна & $3,88 \pm 0,16$ & $2,54 \pm 0,12$ & $\mathrm{p}<0,05$ \\
\hline
\end{tabular}

Дослідження якості життя за опитувальником SF-36 в обох групах реабілітації показало, що хворі мали значні обмеження у фрізичному i психологічному функціонуванні. Найбільше були знижені показники фрізичного здоров'я. Після курсу реабілітації відзначено позитивну динаміку показників якості життя в обох групах, але достовірні поліпшення сумарних шкал фрізичного і психічного компонентів здоров'я відзначалися в основній групі пацієнтів порівняно з контрольною групою. Найбільш виражений приріст в основній групі відбувся за такими показниками: фрізичне фрункціонування - на 22 бала, соціальне фрункціонування - на 20,4 бала, рольове фрізичне фрункціонування - на 17,4 бала, рольове емоційне фрункціонування - на 14,1 бала, психічне здоров'я - на 14 балів, інтенсивність болю - на 13,6 бала. У контрольній групі найбільший абсолютний приріст був лише за показниками: соціальне функціонування - на 9,1 бала, рольове фрізичне функціонування - на 8,8 бала, фрізичне функціонування - на 8,3 бала $(p<0,05)$.

\section{Висновки}

1. Комплексна фрізична реабілітація в умовах стаціонару хворих похилого віку у ранні терміни після перенесеного інсульту з використанням лікувальної гімнастики, лікувального масажу та електростимуляції м'язів з біологічно зворотним зв'язком дозволяє досягти позитивних статистично достовірних змін таких показників, як рухливість суглобів, момент сили згиначів і розгиначів гомілки та стегна, рухові функції та координація рухів, а також м'язовий тонус верхньої кінцівки.

2. Про ефективність використаного методичного підходу свідчать позитивні зміни зовнішнього дихання та стійкості до гіпоксії, індексу Робінсона та адаптаційного потенціалу серцевосудинної системи, підвищення активності хворих у повсякденному житті, його якості, а також покращення показників реактивної та особистісної тривожності.

3. Отримані результати дозволяють рекомендувати запропонований реабілітаційний комплекс для впровадження в практику фрізичної та реабілітаційної медицини.

Перспективи подальших досліджень ми вбачаємо у вивченні ефективності комбінації елементів реабілітаційного комплексу під час фрізичної реабілітації хворих після перенесеного інсульту на стаціонарному, санаторному та амбулаторнополіклінічному етапах реабілітації, зокрема - при використанні вольового керування диханням. 


\section{Література}

1. Аронов Д. М. Функциональные пробы в кардиологии / Д. М. Аронов, П. М. Лупанов. - М.: МЕДпресс-информ, 2007. - 328 с.

2. Белова А. Н. Шкалы, тесты и опросники в медицинской реабилитации / А. Н. Белова, О. Н. Щепетова. - М.: Антидор, 2002. - С. 252-253.

3. Бельская Г. Н. Оценка психоэмоционального статуса и качества жизни больных в остром периоде ишемического инсульта / Г. Н. Бельская, Л. В. Лукьянчикова // Вестн. Южно-Урал. гос. ун-та. Серия: Психология. - 2013. - № 6 (3). - 110-115.

4. Бугрова С. Г. Реабилитация больных, перенесших инсульт, в условиях городской поликлиники / С. Г. Бугрова // Міжнар. неврол. журн. 2011. - №3. - С. 95-101.

5. Епифанов В. А. Реабилитация обследованных, перенесших инсульт / В. А. Епифанов, А. В. Епифанов. - М.: МЕДпресс-информ 2-е изд., испр. и доп.; 2013. -248 с.

6. Стаховской Л. В. Инсульт: рук. для врачей / Л. В. Стаховской, ред. С. В. Котова. - М. : МИА, 2014. - 400 с.

7. Данилова В. И. Инсульт. Современные подходы диагностики, лечения и профилактики / В. И. Данилова, ред. Д. Р. Хасанова. - М.: ГЭОТАР-Медиа, 2014. - 248 с.

8. Кузнецова С. М. Діагностика стану серцево-судинної системи у хворих похилого віку, які перенесли кардіоемболічний ішемічний інсульт на фоні фібриляції передсердь / С. М. Кузнецова, В. В. Кузнецов, М. С. Єгорова // Наукові пропозиції установ НАМН України, які рек. до впровадження у практику охорони здоров'я. - 2013. - С. 19.

9. Мищенко Т. С. Клинические шкалы и психодиагностические тесты диагностики сосудистых заболеваний головного мозга (метод. рек.) / Т. С. Мищенко, Ф. Шестопалова - Х., 2008. - 36 с.

10. Мосенко С. В. Нейрофизиологические аспекты изучения постинсультного двигательного дефицита / С. В. Мосенко // Запорож. мед. журн. - 2006. - № 1, 5 (38). - 113-116.

11. Помаранський О. Активність повсякденного життя осіб, що перенесли мозковий інсульт (за індексом Бартела) / О. Помаранський // Молода спортивна наука України: зб. наук. пр. з галузі фріз. культури та спорту. - Л., 2008. - № 12 (3). - С. 183-186.

12. Реброва О. Ю. Статистический анализ медицинских данных. Применение пакета прикладных программ STATISTIKA / О. Ю. Реброва. - М.: Медиа Сфера, $2002-312$ с.

13. Рокошевська В. В. Модель індивідуальної програми фізичної реабілітації після перенесеного мозкового геморагічного інсульту / В. В. Рокошевська // Молода спортивна наука України : зб. наук. пр. $з$ галузі фізичної культури і спорту. - Л., 2008. - № 12 (3). - С. 193-196.

14. Скворцов Д. В. Диагностика двигательной патологии инструментальными методами: анализ походки, стабилометрия / Д. В. Скворцов, Т. М. Андреева. - М., 2007. - 640 с.

15. Скворцова В. И. Геморрагический инсульт / В. И. Скворцова, В. В. Крылов. - М.: ГЭОТАР-Медиа, 2005. - 160 с.

16. Христова Т. С. Відновлення рухової функції хворих зрілого віку після інсульту засобами фізичної реабілітації / Т. С. Христова // Педагогіка, психологія та медико-біологічні проблеми фізичного виховання і спорту. - 2013. - № 2. - С. 87-91.

17. Яркаев А. А. Лечение и профилактика респираторных осложнений у больных с острым нарушением мозгового кровообращения / А. А. Яркаев. - Казань: ИПЦ Эспресс-формат. - 2008. - 224 с.

\section{References}

1. Аронов ДМ, Лупанов ВП. Функциональные пробы в кардиологии [Functional tests in cardiology]. Москва : МЕДпресс-информ; 2007. $328 \mathrm{c}$.

2. Белова АН, Щепетова ОН. Шкалы, тесты и опросники в медицинской реабилитации [Scales, tests and questionnaires in medical rehabilitation]. Москва: Антидор; 2002;252-3.

3. Бельская ГН, Лукьянчикова ЛВ. Оценка психоэмоционального статуса и качества жизни больных в остром периоде ишемического инсульта [Evaluation of the psycho-emotional status and quality of life of patients in the acute period of ischemic stroke]. Вестник Южно-Уральского государственного университета. Серия: Психология. 2013;6 (3):110-5.

4. Бугрова СГ. Реабилитация больных, перенесших инсульт, в условиях городской поликлиники [Rehabilitation of stroke patients in a city polyclinic]. Міжнародний неврологічний журнал. 2011;3:95-101.

5.Епифанов ВА, Епифанов АВ. Реабилитация обследованных, перенесших инсульт [Rehabilitation of inspected stroke patients]. 2-е изд., испр. и доп. Москва: МЕДпресс-информ; 2013. 248 с.

6. Стаховской ЛВ, Котова СВ, редактор. Инсульт: руководство для врачей [Stroke: a guide for doctors]. Москва: МИА; 2014. 400 C.

7. Данилов ВИ, Хасанова ДР, редакторы. Инсульт. Современные подходы диагностики, лечения и профилактики [Stroke. Current approaches to diagnosis, treatment and prevention]. Москва: ГЭОТАР-Медиа; 2014. 248 с.

8. Кузнецова СМ, Кузнецов ВВ, Єгорова МС. Діагностика стану серцево-судинної системи у хворих похилого віку, які перенесли кардіоемболічний ішемічний інсульт на фоні фібриляції передсердь [Diagnosis of the cardiovascular system state of the elderly patients who have undergone cardioembolic ischemic stroke on the background of atrial fibrillation]. Наукові пропозиції установ НАМН України, які рекомендовано до впровадження у практику охорони здоров'я. 2013, С. 19.

9. Мищенко ТС, Шестопалова Ф. Клинические шкалы и психодиагностические тесты диагностики сосудистых заболеваний головного мозга [Clinical scales and psychodiagnostic tests for the diagnosis of vascular diseases of the brain]. Харьков; 2008. 36 c.

10. Мосенко СВ. Нейрофизиологические аспекты изучения постинсультного двигательного дефицита [Neurophysiological aspects of the study of post-stroke motor deficit]. Запорожский медицинский журнал. 2006;1; 5 (38):113-6.

11. Помаранський О. Активність повсякденного життя осіб, що перенесли мозковий інсульт (за індексом Бартела) [Everyday activity of patients after brain stroke (according to Bartel index)]. Молода спортивна наука України: зб. наук. пр. Львів. 2008;12 (3):183-6.

12. Реброва ОЮ. Статистический анализ медицинских данных. Применение пакета прикладных программ STATISTIKA [Statistical analysis of medical data. STATISTIKA application package]. Москва: Медиа Сфрера; 2002. 312 с.

13. Рокошевська ВВ. Модель індивідуальної програми фізичної реабілітації після перенесеного мозкового геморагічного інсульту [Model of individual physical rehabilitation program after a cerebral hemorrhagic stroke ]. Молода спортивна наука України: зб. наук. пр. Львів. 2008;12 (3):193-6.

14. Скворцов ДВ, Андреева ТМ. Диагностика двигательной патологии инструментальными методами: анализ походки, стабилометрия [Diagnosis of motor pathology by instrumental methods: gait analysis, stabilometry]. Москва; 2007. 640 C.

15. Скворцова ВИ, Крылов ВВ. Геморрагический инсульт [Hemorrhagic stroke]. Москва: ГЭОТАР-Медиа; 2005. 160 с.

16. Христова ТС. Відновлення рухової функції хворих зрілого віку після інсульту засобами фрізичної реабілітації [Restoration of motor function of patients of mature age after stroke by means of physical rehabilitation]. Педагогіка, психологія та медико-біологічні проблеми фізичного виховання і спорту. 2013;2:87-91.

17. Яркаев АА. Лечение и профилактика респираторных осложнений у больных с острым нарушением мозгового кровообращения [Treatment and prevention of respiratory complications in patients with acute cerebrovascular accident]. Казань: ИПЦ Эспрессформат; 2008. 224 c. 